Bolm Inst. oceanogr., S Paulo, 26:1-10, 1977

\title{
ANALYSIS METHOD OF INTRACELLULAR IRON ACCUMULATED IN PHYTOPLANKTON
}

\author{
JORGE FALCÃO PAREDES ${ }^{1}$ \& GILDA SCHMIDT \\ Instituto Oceanográfico da Universidade de São Paulo
}

\section{SYNOPS IS}

A colorimetric method for the assessment of iron accumulated in the cells of phytoplankton utilizing potassium ferrocyanide was developed. Two experiences with Phaeodactylum tricomutum and Chlorella sp. were carried out: the first one, on uptake of the iron relatively to the age of the culture: the second one, on the iron uptake by the cells, relatively to different concentrations of the chelator EDTA.

\section{INTRODUCTION}

Iron is one of the cations that plays an important role in the metabolism and behaviour of the phytoplankton (Ryther \& Kramer, 1961). It is constitutional part of many enzimes and cytochromes and of certain porphyrins. Thus, the growth of algae should be closely related with the iron uptake. Therefore, the concentration of this cation in the unicellular algae

1 Instituto Oceanogräfico's visiting professor from Instituto de Investigação Científica de Angola, financed by O.E.A.

Present address: Centro de Pesquisas e Desenvolvimento. Salvador, BA Brasil.

PUBL. NO 387 DO INST. OCEAN. DA USP. 
should be much concerned to chelators concentration in the environment. Indeed, it is known how the mineral euthrofication of aquatic environment fails out if it has not been accomplished by convenient concentration of chelators, which promotes its solubility (Doig \& Martin, 1971). Some authors have pointed out that fluctuability of unicellular algae shows a great variation during the culture growing and consequently with the environmental conditions. The ability of the phytoplankton buoyancy, according to Gross \& Zeuthen (1948) and Paredes (1968a), would be related with the specific weight of cells. This will mean that the specific gravity variation may result from ionic exchanges, ensured by permeability of the selective cellular membrane, among its own chelators and environmental ones. From these points of view, the importance between the soluble iron concentration in water, and that one accumulated by cells, in their contents, can be quite relevant.

Since the atomic absorption method is not often available, the method developed and here described seems to assume a simplified methodology concerning to the other known methods.

\section{METHODS}

1. Species: Cultures of Phaeodactylum tricornutum and Chlorella sp. isolated from the Cananeia estuary (São Paulo State, Brazil) were utilized in the experiments.

2. Medium and culture conditions: Provasoli medium $\mathrm{ASP}_{2}$ was used to culture those species which grew under fluorescent light, intensity of $5.10^{3}$ lux, $24.0^{\circ} \mathrm{C} \pm 1.0^{\circ} \mathrm{C}$, and $\mathrm{pH}=7.0$, verified after autoclaving. $250 \mathrm{ml}$ conical Pyrex flasks were used with $150 \mathrm{ml}$ of medium.

3. Method developed

3.1. Reagents:

Perchloric acid $70 \%$

Hidrochloric acid 1,5 N

Potassium ferrocyanide $2 \%$ (made up just before using) 


\subsection{Procedure:}

$3 \mu$ Millipore $25 \mathrm{~mm}$ white membrane with dry algae bulk were digested in $3 \mathrm{ml}$ of perchloric acid until almost total dryness in $50 \mathrm{ml}$ beakers by direct heating. After cooling, add $1 \mathrm{ml}$ of 1,5 N HCL and $3 \mathrm{ml}$ of potassium ferrocyanide solution. A blue color is, then, developed. Its stability was reached in about 20-30 minutes. The optical density was performed at $477 \mathrm{m \mu}$, as the most convenient wave length achieved. The readings were obtained at a Beckman DU spectrophometer using $1 \mathrm{~cm}$ silica cells.

3.3. "Blank" and standard solution:

The "blank" was made up as the samples, with a membrane of the same package used for the sampling. The standard solution were prepared with $20 \mathrm{mg}$ of $\mathrm{FeCl}_{3}$ in $400 \mathrm{ml}$ of bidistilled water to give a solution with $50 \mu \mathrm{g} / \mathrm{ml}$. Six aliquots of 1, 2, 5, 10, 25, and $50 \mu \mathrm{g} \mathrm{Fe}$ were treated as the samples and these data were ploted in the calibration curve showed in Figure 1 .

4. Estimation of growth: Cells counting were performed in a counting slide and the density of the suspension was given by a Spectronic $20 \mathrm{Ab}-$ sorptionmeter.

\section{RESULTS}

$1^{\text {st }}$ Experiment :

Iron accumulation in Chlorella $s p$. regarding to age of culture was tested. Three subcultures inoculated with $0.5 \mathrm{ml}$ of a dense old stock of Chlorella $s p$. were harvested successively after two, four, and six days on $3 \mu$ Millipore membranes of known weight. These membranes, dried under $70^{\circ} \mathrm{C}$ for 60 minutes were, after cooling, weighted again. Treated by the method earlier described, it was revealed that Chlorella sp. uptakes much more iron during the earlier stages (lag phase) than during the exponential phase 


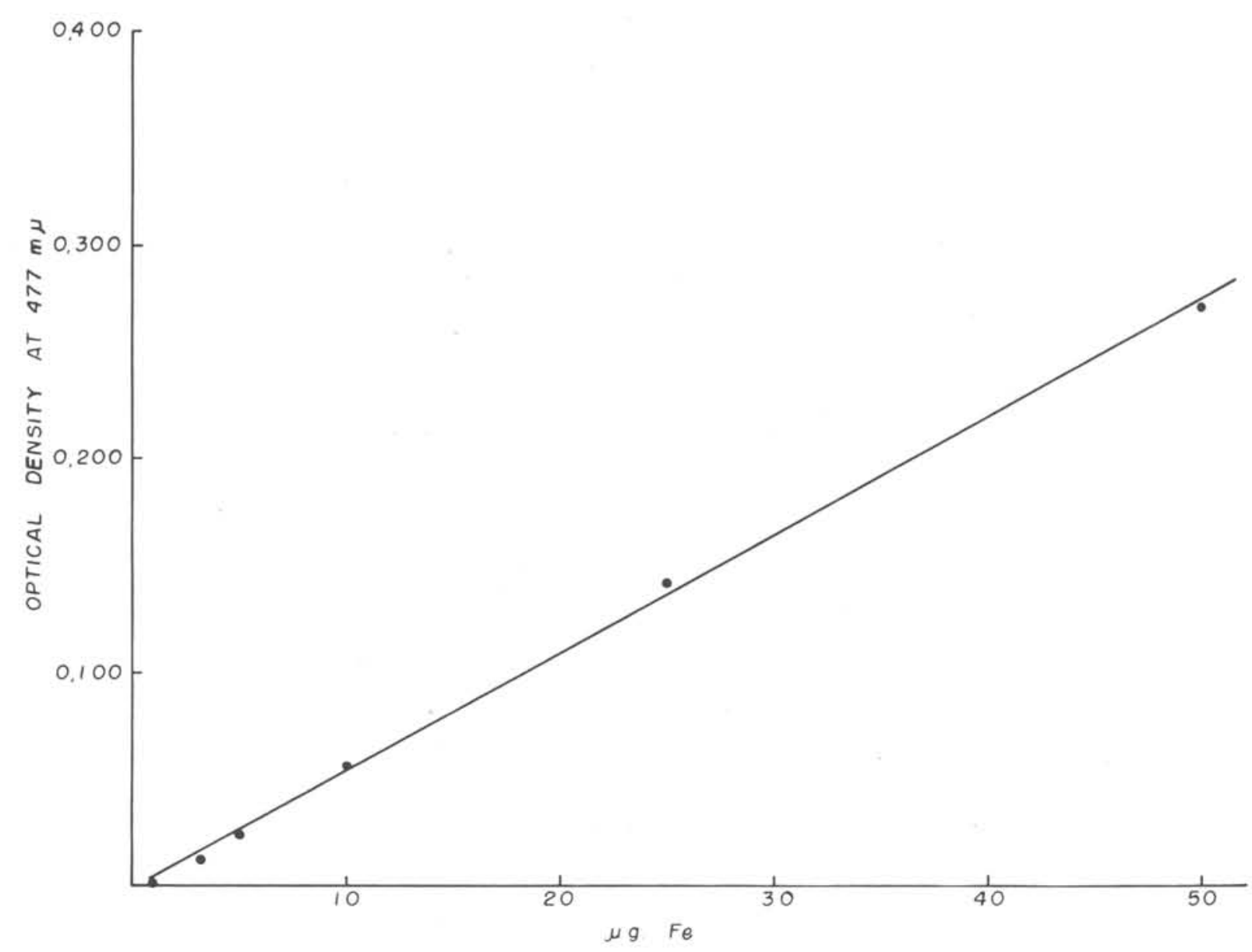

Fig. 1 - Linear calibration of standard $\mathrm{FeCl}_{3}$ solution, at $477 \mathrm{m \mu}$.

(Fig. 2 and Tab. I). Iron rate relatively to dry weight changed between 2.19 and $0.3 \%$. The $\mathrm{pH}$ showed tend to increase during the growth.

$2^{\text {nd }}$ Experiment:

Four subcultures with four different concentrations of EDTA in ASP 2 medium were inoculated with few cells of Phaeodactylum tricomutum and Chlorella sp. (Fig. 3 and Tab. II).

When these subcultures have reached the final stage of exponential phase, $15 \mathrm{ml}$ samples were harvested on $3 \mu$ Millipore membranes of known weight. 

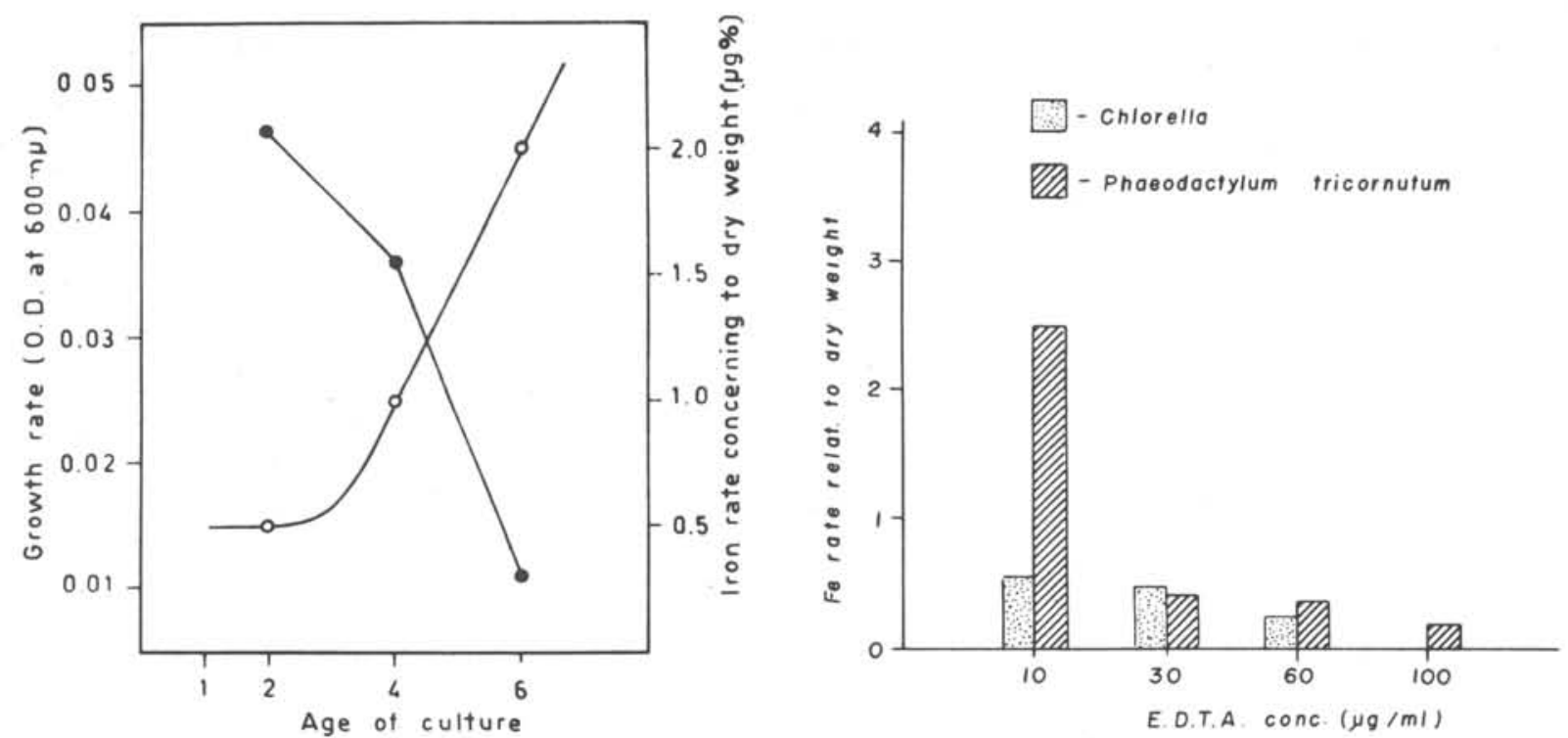

Fig. 2 - Experiment of growth rate and iron assimilation of Chlorella sp. in relation to the age of culture. $\longrightarrow$ growth rate: $\longrightarrow$ iron assimilation.

Fig. 3 - Iron assimilation by ChlorelZa sp. and Phaeodactylum tricormutum as a function of the concentration of EDTA.

TABLE I - Data showing the iron uptake variation in relation to the age of Chlorella sp. culture

\begin{tabular}{|c|c|c|c|}
\hline $\begin{array}{c}\text { AGE IN DAYS } \\
\text { OPTICAL DENSITY } \\
\text { AT } 600 \mathrm{~mL}\end{array}$ & 0.015 & 4 & 6 \\
$\begin{array}{c}\text { CELLS NUMBER/mI } \\
\text { MEAN OF CELL } \\
\text { DRY WEIGHT ( } \mu \text { ) }\end{array}$ & $447 \times 10^{3}$ & $745 \times 10^{3}$ & $1341 \times 10^{3}$ \\
$\begin{array}{c}\text { VARIATION OF INITIAL } \\
\text { PH }=7.0\end{array}$ & $7.0 \times 10^{-5}$ & $4.7 \times 10^{-5}$ & $8.5 \times 10^{-5}$ \\
$\begin{array}{c}\text { IRON RATE CONCERNING } \\
\text { TO DRY WEIGHT (\%) } \\
\text { IRON CONC. CELL ( } \mu \text { Cug) }\end{array}$ & $1.5 \times 10^{-3}$ & $0.7 \times 10^{-3}$ & $0.26 \times 10^{-3}$ \\
\hline
\end{tabular}


TABLE II - Data concerning to the same aged cells suspension given by optical density and to the dry weight given by algal bulk harvested from $15 \mathrm{ml}$

\begin{tabular}{|c|c|c|c|c|}
\hline \multirow{2}{*}{$\begin{array}{c}\text { EDTA } \\
\text { CONC. } \mu \mathrm{g} / \mathrm{ml} 1\end{array}$} & O.D. $600 \mathrm{m \mu}$ & $\begin{array}{c}\text { DRY WEIGHT in } \mu \mathrm{g} \\
\text { (from 15 ml) }\end{array}$ & O.D. 600 mu & $\begin{array}{c}\text { DRY WEIGHT in } \mu \mathrm{g} \\
\text { (from 15 m1) }\end{array}$ \\
\cline { 2 - 5 } & 0.033 & 1.000 & 0.048 & 800 \\
10 & 0.045 & 800 & 0.048 & 1.300 \\
60 & 0.042 & 1.450 & 0.048 & 1.400 \\
100 & 0.040 & 500 & 0.048 & 1.200 \\
\hline
\end{tabular}

The particulate iron uptaken by both species, in terms of iron rates regarding to dry weight, decreases in the opposite way relatively to EDTA concentration.

\section{DISCUSSION}

After Davies (1970) the iron can be present in cultures in four different forms: "that adhering to the culture vessel, that in free suspension in the medium, that adhering to the external surfaces of the cells and that within the cells (as an integral part of the iron porphyrins, cytochromes, and certain enzymes associated with subcellular particles".

The iron in free suspension can still be in ionic or complexed form. Adequated concentrations for the growth of Chlorella sp. have been situated between $1.8 \times 10^{-7}$ to $2.6 \times 10^{-8} \mathrm{M}$.

The high cellular metabolic iron content at the first stage of the growth, i.e. at lag phase and at its sharp decreasing during the exponential phase found out in the conditions described for the first experiment, is 
rather a lot in agreement with results obtained by this author relatively to the growth kinetics of Dunalliela tertiolecta against the iron available in the culture medium.

It is well known that media deficient in iron, above all in darkness, drives to a minor photosynthesis rate reducing consequently the relative growth and becoming the cells chlorotic (Hayward, 1968). The iron deficience seems closely related with a reduction in the synthesis of proteins within the choroplasts, as well as with the falling back in the incorporation of magnesium into the molecule of protoporphyrin. So long we know, the protein synthesis is high during the first stages of the growth decreasing during the logarithmic growth and further on (Paredes, 1968b). However, Davies (1970) showed that Dunaliella tertiolecta under iron deficient conditions is able to adapt gradually to such an environment, being the growth rate much concerned to the metabolic iron content of the cells.

Nielsen \& Wium-Andersen (1970) have pointed down that copper could be an inhibitor for phytoplankton growth in upweling water, where may lie as about $10 \mu \mathrm{g} \mathrm{Cu} / 1$. The copper, if it is complexed in sea water by organic matter, is not poisonous to algae, but if it is in such concentration at ionic form as shown by these authors, the photosynthesis and the phytoplankton growth is rather inhibited.

Goldberg (1952) showed that phytoplankton are not able to uptake the iron which is chelated.

On the other hand, unchelated iron may adhere to the glass of culture vessels (Davies, 1970).

The maximum concentration of soluble iron, i.e., in cationic form at the normal $\mathrm{pH}$ of sea water is $5 \times 10^{-7} \mu \mathrm{g} / 1$. Therefore, iron is mainly present as colloidal ferric hidroxide, ferric phosphate and silicate or still as complexes with organic substances (Riley, 1965).

In order to avoid an over-estimate of flocculated iron, $3 \mu$ Millipore membranes were utilized. However, the absorbed iron on the cells of both species, will come in the assessment together with the metabolized iron, masking the results. 
Paredes (1968c) refers that Exuviella baltica was brought in culture only when an over chelated medium based in aged sea water was used. Also, only under this condition he was able to appreciate the ascension and accumulation of the cells at the surface of culture vessels, which was due to their high buoyancy ability.

Another relevant role of the EDTA is to convert, into soluble, the iron that had became particulated by autoclaving.

Concentrations between 10-100 $\mathrm{g}$ Fe/1 have been recorded in sea water, although concentrations up to $3 \mathrm{mg} \mathrm{Fe} / 1$ have been cited (Riley, 1965). After Wiessner (1962) "when EDTA is present in the nutrient solution, larger quantities of iron must be supplied", otherwise no iron will be available for the cells, since it is in complex form.

This seems to be confirmed with some evidence by the second experiment. Indeed this shows a sharp decrease in the particulated iron concentrations in opposite way to EDTA contents in the culture medium (Fig. 3 and Tab. II).

The dry weights were somewhat contradictory, particularly concerning to Chlorella sp. which will limit, at least, the meaning of the figures on the iron rates.

Although, Chlorella sp. has shown a preferencial growth in $30 \mu \mathrm{g} / \mathrm{ml}$ of EDTA given in terms of cellular density at $600 \mathrm{m \mu}$. On the other hand $P h$. tricomutum has replied with the same growth rate in all EDTA concentrations.

Davies (1970) reports that there is a quantitative relationship between the cellular iron and chlorophyll contents which can be governed by iron chelators. Unfortunately no chlorophyll contents were assessed. In the $100 \mu \mathrm{g} / \mathrm{ml}$ of EDTA subculture no iron response was obtained from the cellular bulk harvested. It is, therefore, inferred that the iron available and that one uptaken, should be in so low concentration that would be under the accuracy of the described method. However, we did not pay attention to the iron "luxury consumption" which, in the lacking of uncomplexed iron, could be enough to support the growth of this subculture. 


\section{RESUMO}

Foi desenvolvido um método para análise do ferro acumulado em células de fitoplâncton, usando ferrocianeto de potássio como agente complexante. Com esse objetivo montaram-se duas experiências: uma em que se mostra o acúmulo de ferro em relação à idade das células e uma segunda experiência onde a assimilação é plotada em função da concentração de EDTA no meio de cultura.

\section{REFERENCES}

DAVIES, A. G. 1970. Iron, chelation and the growth of marine phytoplankton. J. mar. biol. Ass. U. K., 50:65-86.

DOIG III, M. T. \& MARTIN, D. F. 1971. Effect of humic acids on iron analysis in natural waters. Wat. Res., 5:689-692.

GOLDBERG, E. D. 1952. Iron assimilation by marine diatoms. Biol. Bu11. mar. biol. Lab., Woods Hole, 102:243-248.

GROSS, F. \& ZEUTHEN, E. 1948. The buoyancy of plankton diatoms: a problem of cell physiology. Proc. R. Soc., ser. B, 135:382-389.

HAYWARD, J. 1968. Studies on the growth of Phaeodactylum tricornutum. J. mar. biol. Ass. U. K., 48:295-302.

NIELSEN, E. S. \& WIUM-ANDERSEN, S. 1970. Copper ions as poison in the sea and fresh water. Mar. Biol., 6(2):93-97.

PAREDES, J. F. 1968a. Studies on cultures of marine phytoplankton. I. Diatom Ditylum brightwellii West. Mems Inst. Invest. cient. Moçamb., ser. A., 9:156-183.

$1968 \mathrm{~b}$. Studies on cultures of marine phytoplankton. III. Chlorophycean Micromonas squamomata. Mems Inst. Invest. cient. Moçamb., sér. A., 9:249-292.

1968c. Studies on cultures of marine phytoplankton. II. Exuviella baltica bloom with reference to a red tide occurred in the coast of Angola. Mems Inst. Invest. cient. Moçamb., ser. A., 9:184-247.

RILEY, J. P. 1965. Analytical chemistry of sea water. In: Riley, J. P. \& Skirrow, G., ed. - Chemical oceanography. London, Academic Press, vol. 2, p. 378 . 
RYTHER, J. H. \& KRAMER, D. D. 1961. Relative iron requirements of some coastal and offshore plankton algae. Ecology, 43:444-446.

WIESSNER, W. 1962. Inorganic micronutrients. In: Lewin, R. A., ed. - Physiology and biochemistry of algae. New York, Academic Press, 929 p.

(Recebido em 27/maio/1975) 